ISSN: 1858-4837; E-ISSN: 2598-019X

Volume 16, Nomor 2 (2021),

https://jurnal.uns.ac.id/region

DOI: $10.20961 /$ region.v16i2.30842

\title{
Tingkat kesesuaian infrastruktur Kampung Batik Laweyan Kota Surakarta berdasarkan konsep ramah lingkungan
}

\author{
The level of suitability of Kampung Batik Laweyan's infrastructure in Surakarta \\ based on environmentally friendly concepts
}

\author{
A A Anugrahaningrum ${ }^{1}$, G Yudana ${ }^{1}$, dan I Aliyah ${ }^{1}$ \\ ${ }^{1}$ Program Studi Perencanaan Wilayah dan Kota, Fakultas Teknik, Universitas Sebelas \\ Maret
}

Corresponding author's email: andipapriniata@gmail.com

\begin{abstract}
Abstrak. Perkembangan Kampung Batik Laweyan yang berfungsi sebagai permukiman, pariwisata, dan aktivitas industri tidak terlepas dari elemen-elemen di dalamnya; salah satunya yaitu ketersediaan infrastruktur. Infrastruktur ramah lingkungan merupakan konsep yang diperlukan dalam sebuah kawasan untuk mewujudkan ruang yang aman, nyaman, dan berkelanjutan tanpa menimbulkan pencemaran lingkungan. Akan tetapi pada kenyataannya, infrastruktur di Kampung Batik Laweyan masih menimbulkan beberapa permasalahan, salah satunya yaitu terlihat dari kondisi Sungai Jenes yang masih tercemar. Permasalahan tersebut menjadi hal yang penting untuk diperhatikan karena akan berpengaruh terhadap berjalannya aktivitas di Kampung Batik Laweyan. Menteri Perindustrian Indonesia pun menghimbau agar seluruh sentra industri batik yang tersebar di seluruh wilayah Indonesia menjadi sentra yang ramah lingkungan. Penelitian ini bertujuan untuk mengetahui tingkat kesesuaian infrastruktur Kampung Batik Laweyan Kota Surakarta berdasarkan konsep ramah lingkungan. Metode yang digunakan dalam penelitian ini adalah metode deduktif dengan analisis data yang digunakan yaitu teknik analisis skoring deskriptif yang disesuaikan terhadap teori terkait. Hasil analisis penelitian menunjukkan bahwa tingkat kesesuaian infrastruktur di Kampung Batik Laweyan termasuk pada tingkat kesesuaian sedang, artinya berdasarkan perhitungan rata-rata pada seluruh variabel menyatakan kondisi infrastruktur di kawasan ini cukup memenuhi terhadap indikator ramah lingkungan. Jenis infrastruktur yang tergolong sangat sesuai terhadap indikator ramah lingkungan adalah jaringan drainase, jaringan air limbah, dan jaringan air bersih. Sedangkan jenis infrastruktur yang dinilai kurang ramah lingkungan adalah jaringan listrik dan pengelolaan persampahan.
\end{abstract}

Received: June 18, 2019; Accepted: July 07, 2019; Available online: July 15, 2021

Copyright $\odot$ 2021, REGION: Jurnal Pembangunan Wilayah dan Perencanaan Partisipatif 
Kata Kunci: Infrastruktur; Kampung Batik Laweyan; Konsep Ramah Lingkungan; Tingkat Kesesuaian

\begin{abstract}
The development of Kampung Batik Laweyan, which has functions of settlement, tourism, and industrial activities, will automatically influence all elements in it. One of them is infrastructure availability. Environmentally friendly infrastructure is a required concept to create a safe, comfortable, and sustainable area without causing any environmental pollution. As a matter of fact, the infrastructure in Kampung Batik Laweyan raises several problems. One of them is seen from the condition of Jenes River which is polluted. These problems become important to consider because it will affect the activities in Kampung Batik Laweyan. The Indonesian Minister of Industry appealed that all batik industry centres throughout Indonesia should become the environmentally friendly area. This study aims to determine the level of suitability of Kampung Batik Laweyan infrastructure based on environmentally friendly concepts. The method used a deductive method with analysis of the data used, namely descriptive scoring analysis techniques that were adjusted to the related theory. The results of the analysis show that the infrastructure suitability level in Kampung Batik Laweyan is moderate, meaning that based on the average calculation of all variables, the condition of infrastructure in this region is sufficient to meet the environmentally friendly indicators. The types of infrastructure that are classified as very suitable for environmentally friendly concept are drainage networks, wastewater networks, and clean water networks. While the types of infrastructure that are considered less environmentally friendly are electricity networks and waste management.
\end{abstract}

Keywords: Environmentally Friendly Concept; Infrastructure; Kampung Batik Laweyan; Level of Suitability

\title{
1. Pendahuluan
}

Kampung merupakan sekumpulan permukiman yang terdiri dari beberapa aktivitas masyarakat untuk mendorong kegiatan sosial ekonomi yang didukung dengan kondisi lingkungan fisiknya. Hal tersebut juga dijelaskan oleh Sumintarsih dan Adrianto [1] bahwa aktivitas peran masyarakat di kampung bertujuan untuk memenuhi kebutuhan hidupnya serta memajukan kampung menjadi bermakna bagi penataan ruang kota. Pada perkembangannya, kampung diharapkan dapat mendukung kegiatan ekonomi untuk meningkatkan kesejahteraan masyarakat maupun kondisi kampung itu sendiri, misalnya program perbaikan kampung atau yang biasa disebut dengan Kampung Improvement Program (KIP). Menurut Basri, Ispurwono, dan Soemardiono [2], Program Perbaikan Kampung (KIP) merupakan pola pembangunan kampung yang berdasarkan pada partisipasti masyarakat dengan tujuan meningkatkan kualitas lingkungan dan memenuhi kebutuhan masyarakat di dalamnya. Melalui Kampung Improvement Program (KIP), kualitas kampung berpotensi meningkat; seperti kebersihan lingkungan permukiman baik melalui penyediaan infrastruktur maupun perilaku masyarakat di dalamnya. Selain itu kampung juga diharapkan dapat mendukung 
kegiatan ekonomi melalui pengembangan potensi yang dimiliki guna meningkatkan kesejahteraan masyarakat yang biasa disebut dengan kampung kreatif.

Kota Surakarta memiliki beberapa jenis kampung kreatif yang dapat mendorong perekonomian masyarakat dari potensi yang dimiliki melalui industri rumah tangga. Salah satu industri rumah tangga yang berada di Kota Surakarta, yaitu sentra batik yang keberadaannya bersamaan dengan lingkup permukiman warga, sehingga biasa disebut dengan kampung batik. Menurut Djoemena [3], Surakarta dikenal sebagai kota produsen batik terbesar di Indonesia serta menjadikan batik sebagai identitas Kota Surakarta. Kampung batik merupakan kawasan permukiman di perkotaan yang di dalamnya terdapat aktivitas produksi membatik oleh masyarakat asal maupun luar permukiman. Kampung batik yang tersebar di Kota Surakarta terdiri dari Kampung Batik Laweyan dan Kampung Batik Kauman.

Kampung Batik Laweyan merupakan suatu kawasan permukiman yang unik, spesifik, dan bersejarah. Kawasan ini merupakan sentra industri batik tertua dan memiliki nilai historis yang tinggi di Kota Surakarta. Keberadaannya sudah ada sejak jaman Kerajaan Pajang yaitu tahun 1546 M. Bukan hanya sebagai kawasan permukiman dan sentra industri, Kampung Batik Laweyan juga memiliki fungsi sebagai kampung wisata. Hal ini didasarkan pada penetapan Kelurahan Laweyan sebagai tujuan destinasi wisata yang bernama Kampung Batik Laweyan oleh Pemerintah Kota Surakarta pada tahun 2004 [4] serta telah ditetapkan bahwa peruntukan kawasan Kecamatan Laweyan Kota Surakarta adalah sebagai industri kreatif, pariwisata cagar budaya, sejarah dan nilai-nilai tradisional, sebagai pariwisata belanja, dan kawasan permukiman berkepadatan tinggi [5].

Ditetapkannya Kampung Batik Laweyan sebagai kampung wisata pada tahun 2004, menjadikan kampung tersebut semakin berkembang serta diminati oleh wisatawan baik dari dalam maupun luar negeri. Perkembangan aktivitas di Kampung Batik Laweyan yang semakin meningkat memberi pengaruh pada elemen-elemen kampung tersebut salah satunya ketersediaan infrastruktur yang menjadi roda penggerak aktivitas di suatu kawasan. Grigg dalam Kodoatie [6] berpendapat bahwa ketersediaan infrastruktur akan berpengaruh pada pertumbuhan ekonomi dalam tatanan kehidupan masyarakat dengan memperhatikan keharmonisan lingkungan sekitarnya. Menurut Warsilan \& Noor [7] infrastruktur merujuk pada sistem fisik yang menyediakan transportasi, pengairan, drainase, bangunan-bangunan gedung dan fasilitas publik yang lain yang dibutuhkan untuk memenuhi kebutuhan dasar manusia dalam lingkup sosial dan ekonomi. Dalam mendukung aktivitas Kampung Batik Laweyan baik sebagai permukiman, pariwisata, maupun sentra industri batik, Pemerintah Kota Surakarta melakukan upaya pengembangan kawasan salah satunya melalui pengembangan infrastruktur dan telah ditetapkan bahwa Kelurahan Laweyan merupakan kawasan prioritas III dalam pengembangan kawasan permukiman yang dilengkapi dengan infrastruktur [8]. Penyediaan infrastruktur yang memadai dalam mendukung aktivitas akan berdampak pada peningkatan kualitas lingkungan serta pertumbuhan ekonomi. Infrastruktur yang ramah lingkungan diperlukan dalam menciptakan suatu kampung yang lestari dan berkelanjutan dalam proses produksi. Kementerian Perindustrian Republik Indonesia juga 
mendorong agar sentra batik yang tersebar di seluruh wilayah Indonesia menjadi sektor usaha yang ramah lingkungan [9]. Konsep ramah lingkungan merupakan suatu konsep yang diusung sebagai usaha menciptakan kawasan dengan memperhatikan ekosistem di sekitarnya (tidak meninggalkan jejak ekologis) serta sifatnya berkelanjutan. Sedangkan, definisi ramah lingkungan dalam penyelenggaraan penataan ruang, yakni mewujudkan ruang wilayah yang aman, nyaman, produktif, dan berkelanjutan yang salah satunya dilakukan dengan perlindungan fungsi ruang dan pencegahan dampak negatif terhadap lingkungan akibat suatu pemanfaatan ruang [10].

Penyediaan infrastruktur di Kampung Batik Laweyan sebagai penggerak utama dalam mendukung fungsi kampung diharapkan sesuai dengan himbauan Menteri Perindustrian yaitu sentra industri yang ramah lingkungan serta tidak terlepas pula dari fungsi lainnya, yaitu sebagai kawasan pariwisata dan permukiman. Oleh karena itu, diperlukan suatu penelitian mengenai tingkat kesesuaian infrastruktur sebagai pendukung aktivitas Kampung Batik Laweyan Kota Surakarta berdasarkan konsep ramah lingkungan sebagai tolok ukur suatu kampung yang lestari, harmonis, dan berkelanjutan.

\section{Metode}

\subsection{Pendekatan penelitian}

Penelitian ini menggunakan pendekatan deduktif, yaitu peneliti menggunakan teori di awal penelitian sebagai kerangka kerja untuk keseluruhan penelitian, yang berfungsi menstrukturkan rumusan masalah, hipotesis penelitian, serta prosedur pengumpulan data. Penelitian ini menggunakan pendekatan deduktif dengan tujuan, yaitu untuk menguji atau memverifikasi suatu teori, sehingga peneliti mengumpulkan teori mengenai konsep ramah lingkungan yang menguji rumusan masalah yang berasal dari teori tersebut. Berbeda dengan pendekatan penelitian induktif yang merupakan penelitian dengan tujuan membangun atau merumuskan suatu teori yang berasal dari uji analisis di lapangan. Dalam pendekatan deduktif, peneliti menggunakan instrumen penelitian untuk mengukur kondisi variabelvariabel infrastruktur di Kampung Batik Laweyan Kota Surakarta. Hasil perolehan data tersebut kemudian diberi skor-skor sesuai dengan indikator yang telah ditentukan sebelumnya sebagai tolok ukur untuk menyesuaikan atau tidak menyesuaikan terhadap teori yang telah dielaborasi.

\subsection{Jenis penelitian}

Jenis penelitian yang dilakukan merupakan penelitian kuantitatif. Penelitian kuantitatif yaitu metode yang memiliki desain penelitian yang jelas sudah ditentukan di awal, variabel, dan data yang ada dapat diukur secara numerik berdasarkan teori yang kemudian hasil penelitiannya dapat digeneralisasi [11]. Metode kuantitatif dalam penelitian ini digunakan dalam tahap pengumpulan data yang menggunakan teknik pengumpulan data primer (observasi, wawancara, dan kuesioner) maupun data sekunder (studi dokumen) yang menggunakan instrumen penelitian dan dilakukan pada sampel tertentu yang representatif. Hasil dari pengolahan data tersebut berguna untuk melakukan perhitungan pada tahap penyusunan hasil penelitian, sehingga memunculkan tingkat kesesuaian infrastruktur 
Kampung Batik Laweyan Kota Surakarta dengan konsep ramah lingkungan sesuai dengan indikator yang telah ditetapkan sebelumnya.

\subsection{Variabel penelitian dan indikator}

Berdasarkan indikator yang telah diperoleh dari perumusan variabel dan sub variabel, kemudian dapat dirumuskan indikator atas masing-masing sub variabel tersebut. Indikator digunakan untuk menentukan nilai sub variabel yang selanjutnya dapat diketahui tingkat kesesuaian infrastruktur Kampung Batik Laweyan Kota Surakarta berdasarkan konsep ramah lingkungan. Penentuan tingkat kesesuaian dilakukan dengan membagi beberapa kategori yaitu dengan penggolongan lebih dari 2. Adapun dalam penelitian ini, peneliti menggunakan 3 penggolongan, yakni kurang sesuai, sesuai, dan sangat sesuai. Penjelasan indikator yang akan digunakan dalam penelitian ini dapat dilihat pada Tabel 1.

Tabel 1. Variabel penelitian dan indikator $[12,13,22-25,14-21]$.

\begin{tabular}{|c|c|c|c|c|}
\hline Variabel & Sub Variabel & Indikator & Skor & Sumber \\
\hline $\begin{array}{l}\text { Jaringan jalan } \\
\text { lingkungan yang } \\
\text { dapat meresap } \\
\text { air hujan }\end{array}$ & $\begin{array}{l}\text { Badan jalan yang } \\
\text { dapat meresap } \\
\text { air }\end{array}$ & $\begin{array}{l}\text { Lebih dari } 50 \% \text { ruas jalan kawasan pada } \\
\text { bagian badan jalan menggunakan jenis } \\
\text { perkerasan berupa paving block } \\
\text { Lebih dari } 50 \% \text { ruas jalan kawasan pada } \\
\text { bagian badan jalan menggunakan jenis } \\
\text { perkerasan berupa aspal } \\
\text { Lebih dari } 50 \% \text { ruas jalan kawasan pada } \\
\text { bagian badan jalan menggunakan jenis } \\
\text { perkerasan berupa paving beton } \\
\text { Lebih dari } 50 \% \text { ruas jalan kawasan pada } \\
\text { bagian bahu jalan menggunakan jenis } \\
\text { perkerasan berupa paving block } \\
\text { Lebih dari } 50 \% \text { ruas jalan kawasan pada } \\
\text { bagian bahu jalan menggunakan jenis } \\
\text { perkerasan berupa aspal } \\
\text { Lebih dari } 50 \% \text { ruas jalan kawasan pada } \\
\text { bagian bahu jalan menggunakan jenis } \\
\text { perkerasan berupa beton }\end{array}$ & 3 & $\begin{array}{l}\text { - Peraturan } \\
\text { Menteri } \\
\text { Negara } \\
\text { Perumahan } \\
\text { Rakyat RI } \\
\text { Nomor } 32 \\
\text { Tahun } 2006 \\
\text { - Puro et al., } \\
2015\end{array}$ \\
\hline $\begin{array}{l}\text { Jaringan listrik } \\
\text { yang } \\
\text { memanfaatkan } \\
\text { sumber daya } \\
\text { energi alternatif }\end{array}$ & $\begin{array}{l}\text { Ketersediaan } \\
\text { jaringan listrik } \\
\text { yang } \\
\text { memanfaatkan } \\
\text { sumber daya } \\
\text { energi alternatif }\end{array}$ & $\begin{array}{l}\text { Pada kawasan telah tersedia jaringan } \\
\text { listrik dan penerangan jalan yang } \\
\text { bersumber dari energi alternatif. } \\
\text { Pada kawasan tidak tersedia jaringan } \\
\text { listrik yang bersumber dari energi } \\
\text { alternatif namun penerangan jalan telah } \\
\text { menggunakan sumber panel surya } \\
\text { Pada kawasan tidak tersedia jaringan } \\
\text { listrik dan penerangan jalan yang } \\
\text { bersumber dari energi alternatif. }\end{array}$ & 3 & $\begin{array}{l}\text { - } \text { Liun, } 2011 \\
\text { - SNI 03-1733- } \\
2004\end{array}$ \\
\hline $\begin{array}{l}\text { Jaringan } \\
\text { drainase yang }\end{array}$ & $\begin{array}{l}\text { Sistem } \\
\text { peresapan dalam }\end{array}$ & $\begin{array}{l}\text { Sumur resapan air hujan telah memenuhi } \\
\text { ketiga syarat berdasarkan SNI }\end{array}$ & 3 & \\
\hline
\end{tabular}




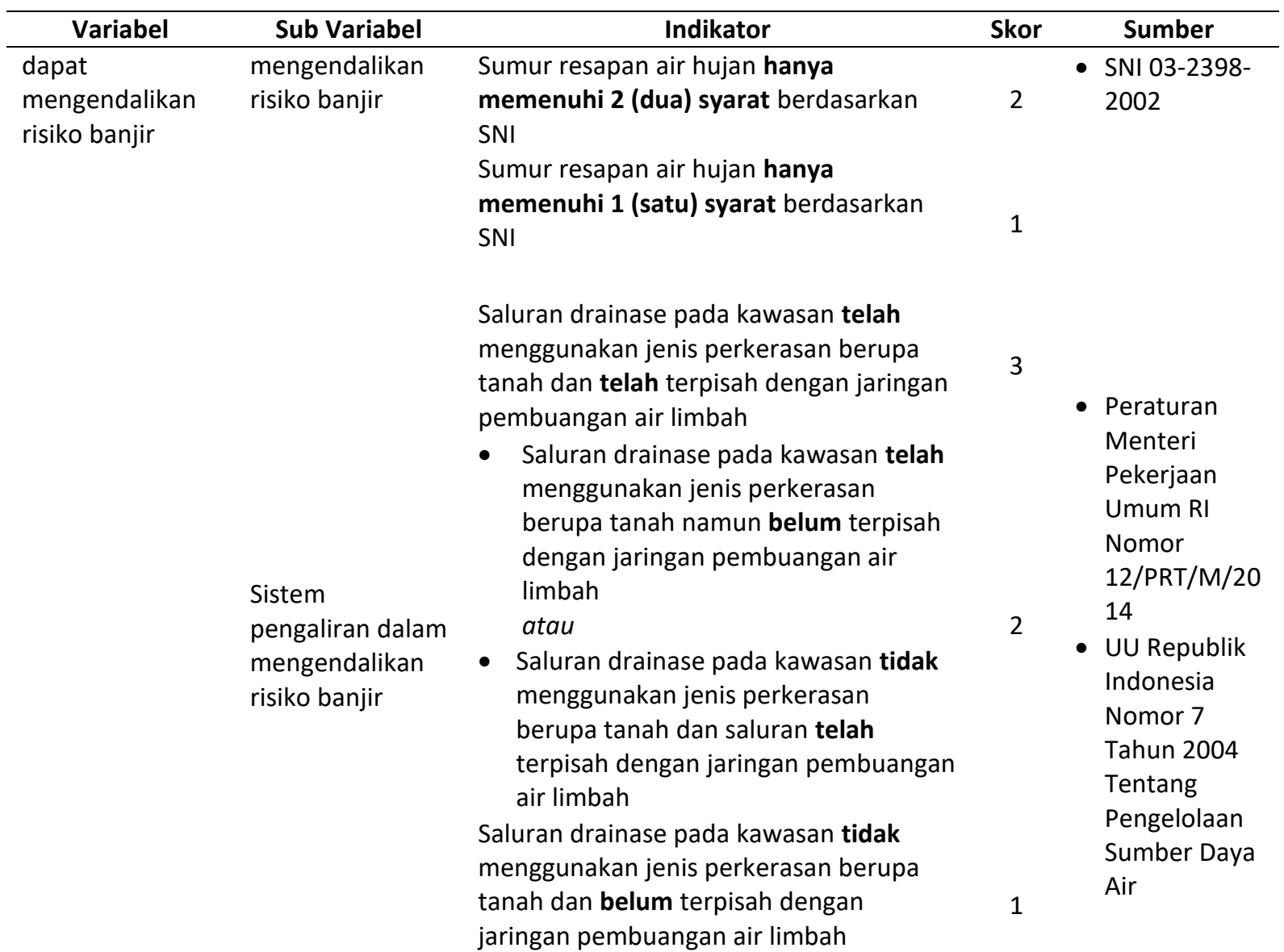

Jaringan air limbah yang

dapat mengendalikan limbah
Lebih dari $50 \%$ jarak septic tank di kawasan terhadap sumber air bersih $>10$

Septic tank dalam mengendalikan limbah meter.

Lebih dari 50\% jarak septic tank di kawasan terhadap sumber air bersih 10 meter.

Lebih dari 50\% jarak septic tank di kawasan terhadap sumber air bersih $<10$ meter.

Sistem pengolahan air limbah pada kawasan telah menggunakan sistem perpipaan dan telah terpisah dari jaringan pembuangan air hujan.

Sistem perpipaan dalam mengendalikan limbah
Sistem pengolahan air limbah pada kawasan telah menggunakan sistem perpipaan namun belum terpisah dari jaringan pembuangan air hujan

Sistem pengolahan air limbah pada kawasan belum tersambung dengan sistem perpipaan
- Peraturan Menteri Perumahan

2 Rakyat RI Nomor 30 Tahun 2011

1

- SNI 03-23982002

- Buku Panduan

3 Penyusunan Rancangan Peraturan

Daerah

$2 \quad$ Tentang Pengelolaan Air Limbah Domestik Tahun 2015

1

- SNI 03-70652005 


\begin{tabular}{|c|c|c|c|c|}
\hline Variabel & Sub Variabel & Indikator & Skor & Sumber \\
\hline & $\begin{array}{l}\text { Pemilahan } \\
\text { sampah dalam } \\
\text { mengendalikan } \\
\text { limbah }\end{array}$ & $\begin{array}{l}\text { Pada kawasan telah tersedia sarana } \\
\text { pemilahan sampah yang telah memenuhi } \\
\text { persyaratan, yaitu dikelompokkan } \\
\text { berdasarkan jenis sampah serta } \\
\text { dibedakan melalui label/tanda dan warna } \\
\text { wadah } \\
\text { Pada kawasan telah tersedia sarana } \\
\text { pemilahan sampah namun tidak } \\
\text { memenuhi persyaratan } \\
\text { Pada kawasan tidak tersedia sarana } \\
\text { pemilahan sampah }\end{array}$ & 1 & $\begin{array}{l}\text { - Peraturan } \\
\text { Pemerintah } \\
\text { (PP) No. } 81 \\
\text { Tahun } 2012\end{array}$ \\
\hline $\begin{array}{l}\text { Pengelolaan } \\
\text { persampahan } \\
\text { dalam upaya } \\
\text { pengendalian } \\
\text { limbah }\end{array}$ & $\begin{array}{l}\text { Pengumpulan } \\
\text { sampah dalam } \\
\text { mengendalikan } \\
\text { limbah }\end{array}$ & $\begin{array}{l}\text { Pada kawasan telah tersedia sarana } \\
\text { pengumpulan sampah berupa TPS yang } \\
\text { telah memenuhi persyaratan, yaitu } \\
\text { memiliki luas dan kapasitas sesuai } \\
\text { kebutuhan. } \\
\text { Pada kawasan telah tersedia sarana } \\
\text { pengumpulan sampah berupa TPS namun } \\
\text { tidak memenuhi persyaratan, yaitu } \\
\text { memiliki luas dan kapasitas yang belum } \\
\text { sesuai kebutuhan. } \\
\text { Pada kawasan tidak tersedia sarana } \\
\text { pengumpulan sampah berupa TPS. }\end{array}$ & 1 & $\begin{array}{l}\text { - Peraturan } \\
\text { Pemerintah } \\
\text { (PP) No. } 81 \\
\text { Tahun } 2012\end{array}$ \\
\hline & $\begin{array}{l}\text { Pengolahan } \\
\text { sampah dalam } \\
\text { mengendalikan } \\
\text { limbah }\end{array}$ & $\begin{array}{l}\text { Pada kawasan telah tersedia sarana } \\
\text { pengolahan sampah berupa TPS } 3 \mathrm{R} \text { yang } \\
\text { telah memenuhi persyaratan, yaitu } \\
\text { memiliki luas minimal } 200 \mathrm{~m}^{2} \text {, tersedia } \\
\text { pengelompokkan sampah organik dan } \\
\text { non organik, bukan merupakan bangunan } \\
\text { permanen, serta metode pengolahan } \\
\text { sampah berbasis masyarakat seperti bank } \\
\text { sampah. } \\
\text { Pada kawasan telah tersedia sarana } \\
\text { pengolahan sampah berupa TPS } 3 \mathrm{R} \\
\text { namun tidak memenuhi persyaratan. } \\
\text { Pada kawasan tidak tersedia sarana } \\
\text { pengolahan sampah berupa TPS } 3 \mathrm{R} \text {. }\end{array}$ & 1 & $\begin{array}{l}\text { - Peraturan } \\
\text { Pemerintah } \\
\text { (PP) No. } 81 \\
\text { Tahun } 2012 \\
\text { - Peraturan } \\
\text { Menteri } \\
\text { Pekerjaan } \\
\text { Umum } \\
\text { Nomor } \\
\text { 03/PRT/M/20 } \\
\text { 13 }\end{array}$ \\
\hline
\end{tabular}

$\begin{array}{ll}\text { Jaringan air } & \text { Ketersediaan } \\ \text { bersih yang } & \text { jaringan air } \\ \text { dapat } & \text { bersih yang } \\ \text { meningkatkan } & \text { dapat } \\ \text { kualitas air } & \text { meningkatkan } \\ & \text { kualitas air }\end{array}$

Jaringan air bersih pada kawasan secara teknis telah memenuhi standar, yaitu disalurkan melalui saluran perpipaan tertutup dan menghasilkan kualitas air yang baik (tidak berwarna, tidak berbau, dan tidak berasa).

Jaringan air bersih pada kawasan secara teknis hanya memenuhi salah satu dari standar.
- Peraturan Menteri Negara Perumahan Rakyat RI Nomor 30

2 Tahun 2011 


\begin{tabular}{|c|c|c|c|c|}
\hline Variabel & Sub Variabel & Indikator & Skor & Sumber \\
\hline & & $\begin{array}{l}\text { Jaringan air bersih pada kawasan secara } \\
\text { teknis tidak memenuhi standar. }\end{array}$ & 1 & $\begin{array}{l}\text { - Peraturan } \\
\text { Pemerintah } \\
\text { RI Nomor } 82 \\
\text { Tahun } 2001\end{array}$ \\
\hline $\begin{array}{l}\text { Ruang terbuka } \\
\text { hijau (RTH) yang } \\
\text { dapat } \\
\text { mengendalikan } \\
\text { risiko banjir dan } \\
\text { pencemaran } \\
\text { udara }\end{array}$ & $\begin{array}{l}\text { Luasan RTH yang } \\
\text { dapat } \\
\text { mengendalikan } \\
\text { risiko banjir dan } \\
\text { pencemaran } \\
\text { udara }\end{array}$ & $\begin{array}{l}\text { Pada kawasan telah tersedia } \mathbf{R T H} \text { dengan } \\
\text { luasan } \mathbf{3 0 \%} \text { dari luas kawasan } \\
\text { seluruhnya } \\
\text { Pada kawasan telah tersedia } \mathbf{R T H} \text { dengan } \\
\text { luasan }<\mathbf{3 0 \%} \text { dari luas kawasan } \\
\text { seluruhnya } \\
\text { Pada kawasan tidak tersedia } \mathbf{R T H}\end{array}$ & $\begin{array}{l}2 \\
1\end{array}$ & $\begin{array}{l}\text { - Undang } \\
\text { Undang } \\
\text { Nomor } 26 \\
\text { Tahun } 2007 \\
\text { Tentang } \\
\text { Penataan } \\
\text { Ruang }\end{array}$ \\
\hline
\end{tabular}

\subsection{Teknik pengumpulan data}

Teknik pengumpulan data ini dilakukan untuk memperoleh data mengenai ketersediaan dan kondisi infrastruktur pada Kampung Batik Laweyan. Observasi yang digunakan adalah observasi yang sifatnya pengumpulan data secara langsung dan observasi yang sifatnya memeriksa kembali data yang sudah didapatkan. Teknik pengumpulan data yang kedua yaitu kuesioner dan wawancara yang dilakukan dengan cara menanyakan kebutuhan data penelitian secara langsung kepada narasumber/responden yang dipilih agar diperoleh informasi yang lebih lengkap. Selain observasi, wawancara, dan kuesioner, teknik pengumpulan data yang terakhir, yaitu survei data sekunder yang dilakukan dengan mengeksplorasi data sekunder kepada instansi Pemerintah Kota Surakarta maupun data penelitian yang sebelumnya baik berupa deskripsi, peta, tabel, maupun foto.

\subsection{Teknik sampling}

Dalam menentukan jumlah sampel, populasi masyarakat pengguna infrastruktur, yaitu seluruh masyarakat (populasi terbatas/finit) yang berada pada Kampung Batik Laweyan yaitu terdiri dari 3 (tiga) RW dan berjumlah 2144 jiwa atau 699 KK. Adapun dalam menentukan jumlah sampel yang akan digunakan yaitu dengan menggunakan rumus nazhir yaitu sebagai berikut:

$$
n=\frac{N \times p(1-p)}{D(N-1)+p(1-p)}
$$

Di mana:

$$
\begin{array}{ll}
\mathrm{N} & =\text { jumlah sampel } \\
\mathrm{N} & =\text { jumlah populasi } \\
\mathrm{p} & =\text { proporsi responden }(90 \%) \\
\mathrm{D} & =\frac{b^{2}}{4}=\frac{0,05^{2}}{4}=0,000625 \\
\mathrm{~b} & =\text { bound of error }(5 \%)
\end{array}
$$


Penghitungan sampel:

$$
\begin{gathered}
n=\frac{699 \times 0,9(1-0,9)}{0,000625(699-1)+0,9(1-0,9)} \\
n=\frac{62,91}{0,44+0,09} \\
n=\frac{62,91}{0,53} \\
n=118,70 \sim 119 K K
\end{gathered}
$$

Jadi sampel yang akan digunakan berdasarkan jumlah populasi yaitu KK sebanyak 119 sampel kuesioner. Dari 119 sampel akan disebar ke dalam 3 RW secara acak.

\section{Hasil penelitian dan pembahasan}

\subsection{Gambaran umum kawasan penelitian}

Kampung Batik Laweyan merupakan salah satu kampung batik yang berada di Kota Surakarta, tepatnya berada di bagian barat Kota Surakarta, memiliki luas wilayah 24,8 ha serta terdiri dari 3 RW dan 10 RT. Jumlah penduduk di Kampung Batik Laweyan sebanyak 2035 jiwa dan 699 KK. Secara geografis Kampung Batik Laweyan terletak pada $110^{\circ} \mathrm{BT}-111^{\circ} \mathrm{BT}$ dan $7,6^{\circ} \mathrm{LS}-8^{\circ}$ LS. Peta kawasan Kampung Batik Laweyan dapat dilihat pada Gambar 1.

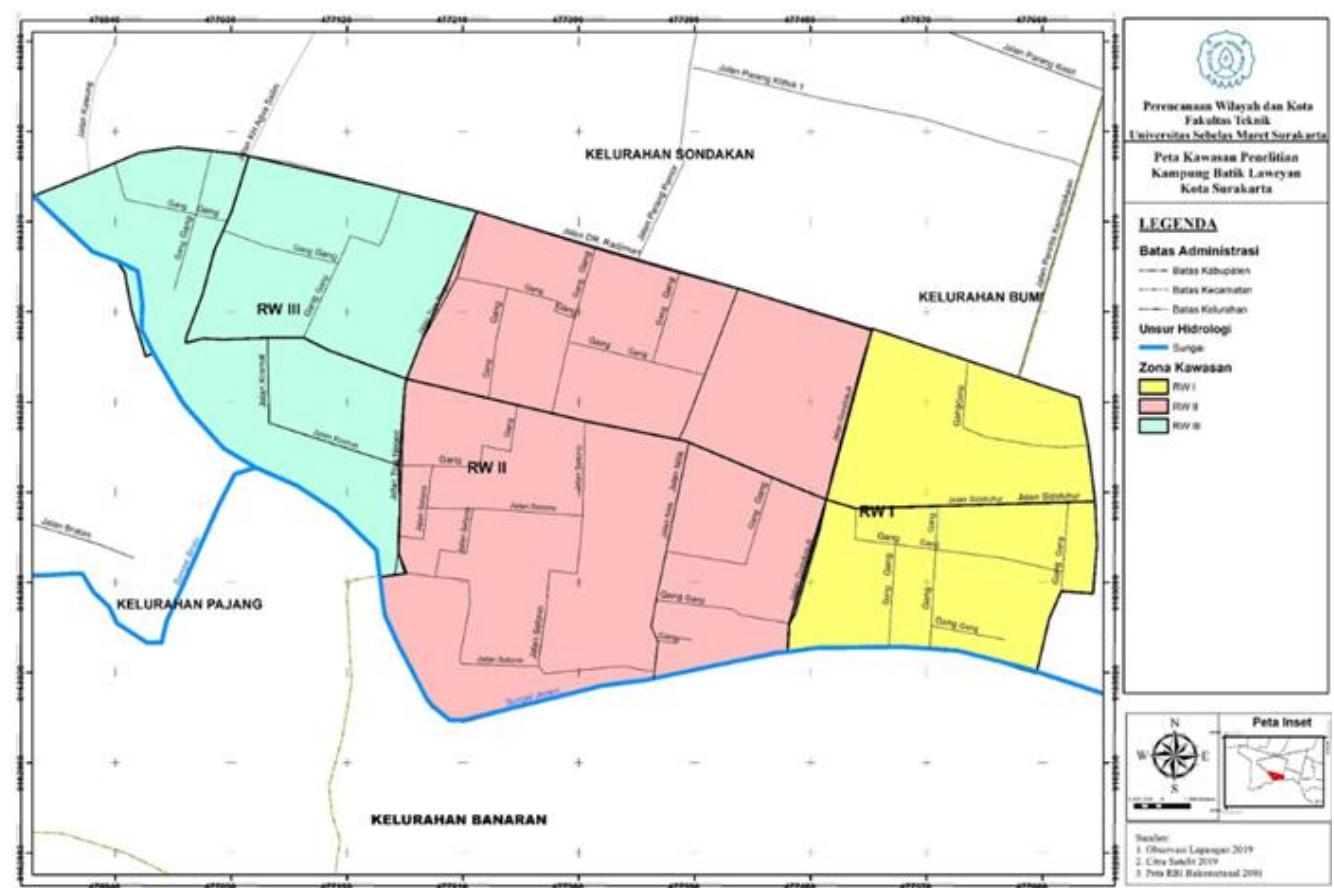

Gambar 1. Peta kawasan penelitian (Kampung Batik Laweyan Kota Surakarta).

Kampung Batik Laweyan ini memiliki beberapa fungsi aktivitas, yaitu fungsi sebagai hunian (permukiman), kegiatan industri batik rumah tangga, serta pariwisata. Potensi pengembangan 
Kampung Batik Laweyan sebagai kampung wisata telah ditetapkan oleh Pemerintah Kota Surakarta sejak tahun 2004. Ditetapkannya Kampung Batik Laweyan sebagai kampung wisata didasarkan atas potensi sentra batik yang sudah ada sejak jaman Kerajaan Pajang dan masih bertahan hingga sekarang, ditambah dengan banyaknya pengunjung baik wisatawan dalam maupun luar negeri. Sebagai kampung yang memiliki daya tarik baik dari segi wisata maupun industri rumah tangga, tidak dipungkiri bahwa ketersediaan infrastruktur yang memadai penting untuk diperhatikan dalam mendukung aktivitas di dalamnya.

\subsection{Data dan analisis}

Kampung Batik Laweyan merupakan suatu kawasan yang memiliki beberapa fungsi aktivitas; yaitu sebagai permukiman, industri rumah tangga, dan pariwisata. Untuk mendukung fungsi tersebut, tak terlepas dari peran infrastruktur sebagai penunjang aktivitas. Infrastruktur di Kampung Batik Laweyan terdiri dari jalan lingkungan, jaringan listrik, jaringan pembuangan air, pengelolaan persampahan, jaringan air bersih, dan ruang terbuka hijau (RTH). Masingmasing jenis infrastruktur tersebut memiliki peran dan fungsi yang berbeda, sesuai dengan penggunaannya pada fungsi kawasan. Pada masing-masing jenis infrastruktur dilakukan analisis skoring untuk memberi penilaian terhadap kondisi eksisting di Kampung Batik Laweyan berdasarkan komponen ramah lingkungan dari indikator yang telah dirumuskan. Analisis skoring diawali dengan memberi penilaian pada masing-masing jenis infrastruktur Kampung Batik Laweyan.

3.2.1 Jalan lingkungan yang ramah lingkungan. Jalan yang ramah lingkungan merupakan jalan yang dapat meresap air sebagai upaya mengurangi risiko banjir atau genangan di kawasan. Adapun jalan yang dapat meresap air ditinjau dari bagian perkerasan dan bahu jalan dengan menggunakan jenis perkerasan tertentu. Menurut Puro et al. [13], perkerasan jalan secara umum terdiri dari 3 (tiga) jenis yaitu perkerasan lentur/aspal, perkerasan kaku/beton, dan perkerasan paving block. Dari ketiga jenis perkerasan tersebut, perkerasan jalan yang menggunakan paving block dapat mendukung go green sehingga dinilai sebagai jenis perkerasan yang paling ramah lingkungan karena memiliki daya serap tinggi dan dapat menjaga keseimbangan air tanah. Jenis perkerasan beserta panjang jalan di Kampung Batik Laweyan dapat dilihat pada Tabel 2.

Tabel 2. Panjang ruas jalan berdasarkan jenis perkerasan di Kampung Batik Laweyan.

\begin{tabular}{|c|c|c|c|c|c|c|}
\hline \multirow{3}{*}{ Nama Zona } & \multicolumn{6}{|c|}{ Panjang Ruas Jalan berdasarkan Jenis Perkerasan (Meter) } \\
\hline & \multicolumn{3}{|c|}{ Bagian Badan Jalan } & \multicolumn{3}{|c|}{ Bagian Bahu Jalan } \\
\hline & Aspal & Beton & $\begin{array}{c}\text { Paving } \\
\text { Block }\end{array}$ & Aspal & Beton & $\begin{array}{c}\text { Paving } \\
\text { Block }\end{array}$ \\
\hline Zona I & 803 & 0 & 316 & 423 & 696 & 0 \\
\hline Zona II & 1014 & 180 & 1311 & 386 & 1963 & 156 \\
\hline Zona III & 355 & 0 & 632 & 27 & 960 & 0 \\
\hline TOTAL & 2172 & 180 & 2259 & 836 & 3619 & 156 \\
\hline
\end{tabular}

Berdasarkan hasil observasi yang telah dilakukan dapat diketahui bahwa ruas jalan pada bagian badan jalan sebagian besar menggunakan jenis perkerasan paving block, sedangkan 
bagian bahu jalan sebagian besar menggunakan jenis perkerasan beton. Skoring kesesuaian variabel jaringan jalan lingkungan yang dapat meresap air hujan dapat dilihat pada Tabel 3.

Tabel 3. Skoring jaringan jalan lingkungan yang dapat meresap air hujan.

\begin{tabular}{|c|c|c|c|c|}
\hline Sub Variabel & Indikator & Skor & Kondisi Eksisting & $\begin{array}{l}\text { Skor yang } \\
\text { didapatkan }\end{array}$ \\
\hline $\begin{array}{l}\text { Bagian } \\
\text { perkerasan } \\
\text { jalan yang } \\
\text { dapat } \\
\text { meresap air }\end{array}$ & $\begin{array}{l}\text { Lebih dari } 50 \% \text { ruas jalan kawasan } \\
\text { pada bagian badan jalan } \\
\text { menggunakan jenis perkerasan } \\
\text { berupa paving block } \\
\text { Lebih dari } 50 \% \text { ruas jalan kawasan } \\
\text { pada bagian badan jalan } \\
\text { menggunakan jenis perkerasan } \\
\text { berupa aspal } \\
\text { Lebih dari } 50 \% \text { ruas jalan kawasan } \\
\text { pada bagian badan jalan } \\
\text { menggunakan jenis perkerasan } \\
\text { berupa paving beton }\end{array}$ & 3 & $\begin{array}{l}\text { Dari } 75 \text { ruas jalan } \\
\text { dengan total panjang } \\
\text { yaitu } 4611 \text { meter, } \\
\text { sebagian besar atau } \\
\text { berkisar } 49 \% \text { di } \\
\text { antaranya yakni total } \\
\text { ruas jalan sepanjang } \\
2259 \text { meter, jalan } \\
\text { lingkungan bagian } \\
\text { badan jalan telah } \\
\text { menggunakan jenis } \\
\text { perkerasan berupa } \\
\text { paving block dengan } \\
\text { kondisi relatif baik. }\end{array}$ & 3 \\
\hline $\begin{array}{l}\text { Bagian bahu } \\
\text { jalan yang } \\
\text { dapat } \\
\text { meresap air }\end{array}$ & $\begin{array}{l}\text { Lebih dari } 50 \% \text { ruas jalan kawasan } \\
\text { pada bagian bahu jalan menggunakan } \\
\text { jenis perkerasan berupa paving block } \\
\text { Lebih dari } 50 \% \text { ruas jalan kawasan } \\
\text { pada bagian bahu jalan menggunakan } \\
\text { jenis perkerasan berupa aspal } \\
\text { Lebih dari } 50 \% \text { ruas jalan kawasan } \\
\text { pada bagian bahu jalan menggunakan } \\
\text { jenis perkerasan berupa beton }\end{array}$ & 1 & $\begin{array}{l}\text { Dari } 75 \text { ruas jalan } \\
\text { dengan total panjang } \\
\text { yaitu } 4611 \text { meter, } \\
\text { sebagian besar atau } \\
\text { berkisar } 79 \% \text { di } \\
\text { antaranya yakni total } \\
\text { ruas jalan sepanjang } \\
3619 \text { meter, jalan } \\
\text { lingkungan bagian bahu } \\
\text { jalan menggunakan jenis } \\
\text { perkerasan berupa } \\
\text { beton dengan kondisi } \\
\text { relatif baik. }\end{array}$ & 1 \\
\hline
\end{tabular}

Infrastruktur berupa jaringan jalan lingkungan di Kampung Batik Laweyan tergolong sangat sesuai dengan indikator ramah lingkungan apabila ditinjau dari bagian badan jalan, karena sebagian besar bagian jalan tersebut menggunakan jenis perkerasan berupa paving block. Sedangkan jaringan jalan lingkungan di Kampung Batik Laweyan yang ditinjau dari bagian bahu jalan tergolong kurang sesuai terhadap indikator ramah lingkungan karena sebagian ruas jalan pada bagian tersebut masih menggunakan jenis perkerasan berupa beton. Penggolongan jenis perkerasan berupa paving block dinilai tahan terhadap genangan air dan mampu sebagai lahan resapan air sehingga dapat menanggulangi risiko banjir yang kemungkinan dapat terjadi saat musim penghujan.

3.2.2 Jaringan listrik yang ramah lingkungan. Jaringan listrik dinilai ramah lingkungan apabila bersumber dari energi alternatif. Pemanfaatan sumber daya energi alternatif di Kampung 
Batik Laweyan ditinjau dari ketersediaan dan kualitasnya. Skoring terhadap variabel jaringan listrik yang ramah lingkungan di Kampung Batik Laweyan ditunjukkan pada Tabel 4.

Tabel 4. Skoring jaringan listrik yang memanfaatkan sumber daya energi alternatif.

\begin{tabular}{|c|c|c|c|c|}
\hline Sub Variabel & Indikator & Skor & Kondisi Eksisting & $\begin{array}{l}\text { Skor yang } \\
\text { didapatkan }\end{array}$ \\
\hline $\begin{array}{l}\text { Ketersediaan } \\
\text { jaringan listrk } \\
\text { yang } \\
\text { memanfaatkan } \\
\text { sumber daya } \\
\text { energi alternatif }\end{array}$ & $\begin{array}{l}\text { Pada kawasan telah } \\
\text { tersedia jaringan listrik } \\
\text { dan penerangan jalan } \\
\text { yang bersumber dari } \\
\text { energi alternatif. } \\
\text { Pada kawasan tidak } \\
\text { tersedia jaringan listrik } \\
\text { yang bersumber dari } \\
\text { energi alternatif namun } \\
\text { penerangan jalan telah } \\
\text { menggunakan sumber } \\
\text { panel surya. } \\
\text { Pada kawasan tidak } \\
\text { tersedia jaringan listrik } \\
\text { dan penerangan jalan } \\
\text { yang bersumber dari } \\
\text { energi alternatif. }\end{array}$ & 2 & $\begin{array}{l}\text { Jaringan listrik yang melayani } \\
\text { Kampung Batik Laweyan } \\
\text { merupakan energi listrik } \\
\text { bersumber dari PLN yang } \\
\text { sebagian besar memperoleh } \\
\text { pasokan listrik berasal dari PLTU } \\
\text { di Pacitan dan Semarang. Sumber } \\
\text { listrik tersebut merupakan } \\
\text { pembangkit listrik berbahan } \\
\text { bakar batu bara artinya memiliki } \\
\text { kemungkinan dapat menimbulkan } \\
\text { emisi CO } 2 \text {. Selain itu, sepanjang } \\
\text { ruas jalan di Kampung Batik } \\
\text { Laweyan telah tersedia } \\
\text { penerangan jalan yang juga } \\
\text { bersumber dari PLN Kota } \\
\text { Surakarta, bukan dari sumber } \\
\text { energi panel surya. }\end{array}$ & 1 \\
\hline
\end{tabular}

Ketersediaan jaringan listrik yang memanfaatkan sumber daya energi alternatif di Kampung Batik Laweyan tergolong kurang sesuai dengan indikator ramah lingkungan. Hal tersebut dikarenakan Kampung Batik Laweyan belum tersedia energi listrik alternatif dan sumber listrik yang digunakan untuk mendukung aktivitas sebagian besar masih berasal dari PLTU. Sedangkan jaringan listrik yang ditinjau dari kelengkapan listrik berupa penerangan jalan di Kampung Batik Laweyan belum diperoleh melalui energi alternatif panel surya melainkan sama seperti jaringan listrik yang tersambung ke saluran rumah tangga, yaitu dari PLN yang sumber energinya berasal dari PLTU.

3.2.3 Jaringan drainase yang dapat mengendalikan risiko banjir. Jaringan pembuangan air di Kampung Batik Laweyan terdiri dari jaringan drainase dan jaringan air limbah. Jaringan drainase menjadi hal yang perlu diperhatikan dalam mendukung aktivitas masyarakat di Kampung Batik Laweyan sehingga diharapkan dapat memenuhi standar dan berwawasan lingkungan. Untuk mengetahui kesesuaian jaringan drainase terhadap indikator ramah lingkungan, dapat ditinjau dari sistem peresapan yang dapat mengendalikan risiko banjir serta sistem pengaliran dalam mengendalikan risiko banjir. Skoring terhadap variabel jaringan drainase yang dapat mengendalikan risiko banjir di Kampung Batik Laweyan dapat dilihat pada Tabel 5. 
Tabel 5. Skoring jaringan drainase yang dapat mengendalikan risiko banjir.

\begin{tabular}{|c|c|c|c|c|}
\hline Sub Variabel & Indikator & Skor & Kondisi Eksisting & $\begin{array}{l}\text { Skor yang } \\
\text { didapatkan }\end{array}$ \\
\hline $\begin{array}{l}\text { Sistem } \\
\text { peresapan } \\
\text { dalam } \\
\text { mengendalikan } \\
\text { risiko banjir }\end{array}$ & $\begin{array}{l}\text { Sumur resapan air hujan } \\
\text { telah memenuhi ketiga } \\
\text { syarat berdasarkan SNI } \\
\text { Sumur resapan air hujan } \\
\text { hanya memenuhi } 2 \\
\text { (dua) syarat } \\
\text { berdasarkan SNI }\end{array}$ & 3 & $\begin{array}{l}\text { Kampung Batik Laweyan memiliki } \\
\text { sumur resapan air sejak tahun } 2005 \\
\text { yang dikelola oleh Dinas Lingkungan } \\
\text { Hidup (DLH) Kota Surakarta serta } \\
\text { berfungsi sebagai tempat } \\
\text { penampungan air hujan guna } \\
\text { mengurangi risiko banjir kawasan. } \\
\text { Sumur resapan di kampung ini } \\
\text { tersedia sebanyak } 10 \text { buah yang } \\
\text { tersebar pada } 2 \text { titik utama yang } \\
\text { termasuk daerah rawan banjir, yaitu } \\
\text { di sekitar Kantor Kelurahan Laweyan } \\
\text { (5 buah sumur resapan) dan di Jalan } \\
\text { Gondosuli (5 buah sumur resapan) } \\
\text { serta keberadaannya jauh dari } \\
\text { timbunan sampah maupun septic } \\
\text { tank, yakni berjarak lebih dari } 5 \\
\text { meter. Adapun kondisi sumur } \\
\text { resapan berfungsi dengan baik, hal } \\
\text { ini terlihat adanya perubahan } \\
\text { sebelum dan setelah dibuatnya } \\
\text { sumur resapan tersebut, yaitu } \\
\text { kawasan tidak terjadi genangan } \\
\text { (banjir) ketika musim penghujan. } \\
\text { Secara teknis, sumur resapan dibuat } \\
\text { dari bahan pipa paralon dengan } \\
\text { ketinggian } 1 \text { m, berlubang di setiap } \\
\text { selimut tabungnya guna mengaliri } \\
\text { kelebihan air yang dialirkan ke } \\
\text { sekitarnya sebagai sumber air tanah }\end{array}$ & 3 \\
\hline
\end{tabular}

Saluran drainase pada

\section{kawasan telah}

menggunakan jenis

perkerasan berupa

tanah dan telah terpisah

Sistem

Pengaliran

dengan jaringan

dalam

mengendalikan

risiko banjir pembuangan air limbah

Saluran drainase pada

kawasan telah

menggunakan jenis

perkerasan berupa

tanah namun belum

terpisah dengan

jaringan pembuangan

air limbah, atau 


\begin{tabular}{|c|c|c|c|c|}
\hline Sub Variabel & Indikator & Skor & Kondisi Eksisting & $\begin{array}{c}\text { Skor yang } \\
\text { didapatkan }\end{array}$ \\
\hline & $\begin{array}{l}\text { Saluran drainase pada } \\
\text { kawasan tidak } \\
\text { menggunakan jenis } \\
\text { perkerasan berupa } \\
\text { tanah dan saluran telah } \\
\text { terpisah dengan } \\
\text { jaringan pembuangan } \\
\text { air limbah } \\
\text { Saluran drainase pada } \\
\text { kawasan tidak } \\
\text { menggunakan jenis } \\
\text { perkerasan berupa } \\
\text { tanah dan belum } \\
\text { terpisah dengan } \\
\text { jaringan pembuangan } \\
\text { air limbah }\end{array}$ & 1 & & \\
\hline
\end{tabular}

Ketersediaan sumur resapan di Kampung Batik Laweyan yang dapat mengendalikan risiko banjir sangat memenuhi indikator ramah lingkungan. Selain karena mencakup semua syarat berdasarkan SNI, ketersediaan sumur resapan air di kawasan ini juga memiliki dampak yang cukup baik terhadap perubahan lingkungan di sekitarnya, yaitu lokasi dibangunnya sumur resapan tidak lagi mengalami genangan (banjir) pada saat musim penghujan. Selain itu juga didapatkan bahwa sistem pengaliran di Kampung Batik Laweyan berupa saluran drainase sangat memenuhi indikator ramah lingkungan. Hal ini dikarenakan sebagian besar yakni lebih dari 50\% saluran drainase pada sepanjang ruas jalan di Kampung Batik Laweyan memiliki jenis perkerasan tanah sebagai daya serap air guna mengendalikan risiko banjir, serta aliran air lancar (tidak menggenang). Namun tidak dapat dipungkiri bahwa jaringan drainase primer pada Kampung Batik Laweyan, yaitu Sungai Jenes masih mengalami kualitas air yang cukup buruk akibat buangan air limbah dari produksi batik maupun pabrik dari luar kawasan yang tidak diolah terlebih dahulu. Selain kualitas air sungai yang buruk (berwarna hitam), tumpukan sampah pun masih tergolong banyak sehingga mengakibatkan aliran air yang tidak berjalan lancar. Jaringan pembuangan air yang dibangun di Kampung Batik Laweyan baik berupa jaringan drainase maupun jaringan air limbah terbangun secara terpisah, sehingga indikator ini dinilai sangat memenuhi dengan indikator ramah lingkungan. Pemisahan jaringan pembuangan air berfungsi untuk mencegah terjadinya pencemaran air bersih. Air hujan yang terserap berguna sebagai sumber air tanah yang apabila penataan jaringan tersebut digabungkan dengan jaringan air limbah, akan berdampak pada kualitas air tanah tersebut. Begitu pula dengan jaringan pembuangan air limbah rumah tangga dengan pembuangan air limbah hasil produksi batik, juga dibangun secara terpisah guna menghindari terjadinya pencemaran lingkungan khususnya bagi pencemaran air dan tanah.

3.2.4 Jaringan air limbah yang dapat mengendalikan limbah. Selain jaringan drainase, jaringan pembuangan air lainnya yang ada di Kampung Batik Laweyan, yaitu jaringan air limbah. Jaringan air limbah yang dinilai ramah lingkungan ditinjau dari ketersediaan septic 
tank dan sistem perpipaan dalam suatu kawasan. Septic tank di Kampung Batik Laweyan difungsikan sebagai tempat penampungan dan pengolahan air limbah rumah tangga yang berasal dari WC kemudian digelontorkan ke IPAL komunal skala kota melalui sistem perpipaan yang dikelola oleh PDAM Kota Surakarta. Septic tank yang ramah lingkungan harus memenuhi syarat berdasarkan standar yang berlaku. Selain septic tank, sistem perpipaan di Kampung Batik Laweyan juga merupakan salah satu komponen jaringan air limbah yang perlu diperhatikan dalam mendukung kesesuaiannya terhadap konsep ramah lingkungan. Skoring mengenai variabel jaringan air limbah yang dapat mengendalikan limbah di Kampung Batik Laweyan dapat dilihat pada Tabel 6.

Tabel 6. Skoring jaringan air limbah yang dapat mengendalikan limbah.

\begin{tabular}{|c|c|c|c|c|}
\hline Sub Variabel & Indikator & Skor & Kondisi Eksisting & $\begin{array}{l}\text { Skor yang } \\
\text { didapatkan }\end{array}$ \\
\hline $\begin{array}{l}\text { Septic tank } \\
\text { dalam } \\
\text { mengendalikan } \\
\text { limbah }\end{array}$ & $\begin{array}{l}\text { Lebih dari } 50 \% \text { jarak } \\
\text { septic tank di kawasan } \\
\text { terhadap sumber air } \\
\text { bersih }>10 \text { meter. } \\
\text { Lebih dari } 50 \% \text { jarak } \\
\text { septic tank di kawasan } \\
\text { terhadap sumber air } \\
\text { bersih } 10 \text { meter. }\end{array}$ & 1 & $\begin{array}{l}\text { Seluruh rumah penduduk di } \\
\text { Kampung Batik Laweyan tersedia } \\
\text { jaringan air limbah rumah tangga } \\
\text { berupa septic tank. Septic tank } \\
\text { tersebut difungsikan sebagai } \\
\text { penampungan dan pengolahan } \\
\text { limbah dari WC rumah penduduk } \\
\text { dan dialirkan melalui pipa bawah } \\
\text { tanah yang kedap air. Air limbah } \\
\text { rumah tangga yang telah diproses } \\
\text { oleh septic tank, kemudian dialirkan } \\
\text { ke IPAL komunal skala kota yang } \\
\text { berlokasi di Kelurahan Semanggi } \\
\text { melalui jaringan perpipaan. IPAL } \\
\text { komunal skala kota tersebut } \\
\text { melayani air limbah rumah tangga di } \\
\text { Kota Surakarta yang dikelola oleh } \\
\text { PDAM Kota Surakarta. Adapun jarak } \\
\text { lokasi septic tank terhadap sumber } \\
\text { air bersih sebagian besar yaitu }>10 m \text {. }\end{array}$ & 3 \\
\hline $\begin{array}{l}\text { Sistem } \\
\text { perpipaan } \\
\text { dalam } \\
\text { mengendalikan } \\
\text { limbah }\end{array}$ & $\begin{array}{l}\text { Sistem pengolahan air } \\
\text { limbah pada kawasan } \\
\text { telah menggunakan } \\
\text { sistem perpipaan dan } \\
\text { telah terpisah dari } \\
\text { jaringan pembuangan } \\
\text { air hujan. } \\
\text { Sistem pengolahan air } \\
\text { limbah pada kawasan } \\
\text { telah menggunakan } \\
\text { sistem perpipaan } \\
\text { namun belum terpisah } \\
\text { dari jaringan } \\
\text { pembuangan air hujan }\end{array}$ & 3 & $\begin{array}{l}\text { Limbah hasil produksi batik dialirkan } \\
\text { melalui sistem perpipaan yang } \\
\text { kemudian dikelola di IPAL komunal } \\
\text { yang berada di sisi selatan Kampung } \\
\text { Batik Laweyan. Dalam } \\
\text { penggunaannya, beberapa rumah } \\
\text { produksi di Kampung Batik Laweyan } \\
\text { membuang air limbah hasil } \\
\text { produksinya melalui perpipaan yang } \\
\text { dipasang serta terkoneksi pada IPAL } \\
\text { komunal secara gravitasi, yaitu tidak } \\
\text { menggunakan listrik dalam } \\
\text { pengoperasiannya. Pipa yang } \\
\text { menghubungkan dari rumah } \\
\text { produksi hingga IPAL komunal } \\
\text { terpasang di bawah tanah, tertutup, }\end{array}$ & 3 \\
\hline
\end{tabular}




\begin{tabular}{|c|c|c|c|c|}
\hline Sub Variabel & Indikator & Skor & Kondisi Eksisting & $\begin{array}{l}\text { Skor yang } \\
\text { didapatkan }\end{array}$ \\
\hline & $\begin{array}{l}\text { Sistem pengolahan air } \\
\text { limbah pada kawasan } \\
\text { belum tersambung } \\
\text { dengan sistem } \\
\text { perpipaan }\end{array}$ & 1 & $\begin{array}{l}\text { berbahan kedap air, dan terpisah } \\
\text { dengan jaringan drainase yang lain } \\
\text { seperti jaringan pembuangan air } \\
\text { hujan. }\end{array}$ & \\
\hline
\end{tabular}

Ketersediaan septic tank di masing-masing rumah penduduk Kampung Batik Laweyan memperoleh skor 3 yang berarti kondisi eksisting tersebut sangat memenuhi indikator ramah lingkungan dikarenakan $52 \%$ dari keseluruhan rumah penduduk dan fasilitas sosial di kawasan tersebut memiliki septic tank yang berjarak lebih dari 10 meter dari sumber air bersih. Selain itu juga didapatkan bahwa sistem perpipaan limbah baik hasil produksi batik maupun limbah rumah tangga di Kampung Batik Laweyan dibangun secara terpisah dengan jaringan pembuangan air hujan sebagai upaya mencegah terjadinya pencemaran air dan tanah sehingga dinilai sangat memenuhi indikator ramah lingkungan.

3.2.5 Pengelolaan persampahan dalam upaya pengendalian limbah. Sampah menjadi hal yang sangat penting untuk diperhatikan dalam suatu kawasan, terutama pada kawasan yang berkepadatan tinggi, seperti Kampung Batik Laweyan. Aktivitas dalam kampung akan berjalan lancar apabila sampah terkelola dengan baik, artinya tidak ada penumpukan sampah yang dapat mencemari lingkungan. Pengelolaan sampah yang ramah lingkungan ditinjau dari teknis kegiatan atau upaya pengelolaan sampah dimana pada masing-masing kegiatan terwadahi jaringan persampahan. Kegiatan pengelolaan sampah yang dimaksud, yakni pemilahan sampah, pengumpulan sampah, serta pengolahan sampah. Skoring mengenai variabel pengelolaan persampahan dalam upaya pengendalian limbah di Kampung Batik Laweyan dapat dilihat pada Tabel 7.

Tabel 7. Skoring pengelolaan persampahan dalam upaya pengurangan limbah.

\begin{tabular}{|c|c|c|c|c|}
\hline Sub Variabel & Indikator & Skor & Kondisi Eksisting & $\begin{array}{l}\text { Skor yang } \\
\text { didapatkan }\end{array}$ \\
\hline $\begin{array}{l}\text { Pemilahan } \\
\text { sampah dalam } \\
\text { mengendalikan } \\
\text { limbah }\end{array}$ & $\begin{array}{l}\text { Pada kawasan telah } \\
\text { tersedia sarana } \\
\text { pemilahan sampah } \\
\text { yang telah } \\
\text { memenuhi } \\
\text { persyaratan, yaitu } \\
\text { dikelompokkan } \\
\text { berdasarkan jenis } \\
\text { sampah serta } \\
\text { dibedakan melalui } \\
\text { label/tanda dan } \\
\text { warna wadah } \\
\text { Pada kawasan telah } \\
\text { tersedia sarana } \\
\text { pemilahan sampah } \\
\text { namun tidak }\end{array}$ & 2 & $\begin{array}{l}\text { Pemilahan sampah di Kampung Batik } \\
\text { Laweyan dilakukan melalui } \\
\text { pengelompokkan dan memisahkan } \\
\text { sampah sesuai dengan jenisnya. } \\
\text { Sampah yang dihasilkan baik dari } \\
\text { aktivitas rumah tangga, industri, } \\
\text { maupun wisata telah tersedia sarana } \\
\text { atau wadah sampah yang dibedakan } \\
\text { berdasarkan jenis sampahnya melalui } \\
\text { warna dan label sebagai pembeda. } \\
\text { Namun belum semua lokasi di } \\
\text { Kampung Batik Laweyan tersedia } \\
\text { sarana penampungan sampah } \\
\text { tersebut, melainkan masih terdapat } \\
\text { beberapa wadah sampah yang tidak } \\
\text { dipisahkan berdasarkan jenis }\end{array}$ & 3 \\
\hline
\end{tabular}

Received: June 18, 2019; Accepted: July 07, 2019; Available online: July 15, 2021 373 


\begin{tabular}{|c|c|c|c|c|}
\hline Sub Variabel & Indikator & Skor & Kondisi Eksisting & $\begin{array}{l}\text { Skor yang } \\
\text { didapatkan }\end{array}$ \\
\hline & $\begin{array}{l}\text { memenuhi } \\
\text { persyaratan } \\
\text { Pada kawasan tidak } \\
\text { tersedia sarana } \\
\text { pemilahan sampah }\end{array}$ & 1 & $\begin{array}{l}\text { sampahnya (tercampur antara } \\
\text { sampah organik dan non-organik). }\end{array}$ & \\
\hline $\begin{array}{l}\text { Pengumpulan } \\
\text { sampah dalam } \\
\text { mengendalikan } \\
\text { limbah }\end{array}$ & $\begin{array}{l}\text { Pada kawasan telah } \\
\text { tersedia sarana } \\
\text { pengumpulan } \\
\text { sampah berupa TPS } \\
\text { yang telah } \\
\text { memenuhi } \\
\text { persyaratan, yaitu } \\
\text { memiliki luas dan } \\
\text { kapasitas sesuai } \\
\text { kebutuhan. } \\
\text { Pada kawasan telah } \\
\text { tersedia sarana } \\
\text { pengumpulan } \\
\text { sampah berupa TPS } \\
\text { namun tidak } \\
\text { memenuhi } \\
\text { persyaratan, yaitu } \\
\text { memiliki luas dan } \\
\text { kapasitas yang } \\
\text { belum sesuai } \\
\text { kebutuhan. } \\
\text { Pada kawasan tidak } \\
\text { tersedia sarana } \\
\text { pengumpulan } \\
\text { sampah berupa TPS. }\end{array}$ & 1 & $\begin{array}{l}\text { Sampah yang dihasilkan oleh } \\
\text { Kampung Batik Laweyan tidak melalui } \\
\text { tahap pengolahan di Tempat } \\
\text { Pembuangan Sampah Terpadu (TPST) } \\
\text { sejak tahun 2017. Sampah yang telah } \\
\text { dikumpulkan di mobil sampah } \\
\text { langsung ditampung di TPA Putri } \\
\text { Cempo. Siklus tersebut dilakukan } \\
\text { setiap hari. }\end{array}$ & 1 \\
\hline $\begin{array}{l}\text { Pengolahan } \\
\text { sampah dalam } \\
\text { mengendalikan } \\
\text { limbah }\end{array}$ & $\begin{array}{l}\text { Pada kawasan telah } \\
\text { tersedia sarana } \\
\text { pengolahan sampah } \\
\text { berupa TPS 3R yang } \\
\text { telah memenuhi } \\
\text { persyaratan, yaitu } \\
\text { memiliki luas } \\
\text { minimal } 200 \text { m², }^{2} \\
\text { tersedia } \\
\text { pengelompokkan } \\
\text { sampah organik dan } \\
\text { non organik, bukan } \\
\text { merupakan } \\
\text { bangunan }\end{array}$ & 3 & $\begin{array}{l}\text { Masyarakat di Kampung Batik } \\
\text { Laweyan belum memiliki komunitas } \\
\text { maupun kelompok yang berperan } \\
\text { dalam pengolahan sampah daur } \\
\text { ulang maupun pengolahan sampah } \\
\text { bernilai ekonomi (bank sampah). }\end{array}$ & 1 \\
\hline
\end{tabular}




\begin{tabular}{|c|c|c|c|c|}
\hline Sub Variabel & Indikator & Skor & Kondisi Eksisting & $\begin{array}{c}\text { Skor yang } \\
\text { didapatkan }\end{array}$ \\
\hline & $\begin{array}{l}\text { permanen, serta } \\
\text { metode pengolahan } \\
\text { sampah berbasis } \\
\text { masyarakat seperti } \\
\text { bank sampah. }\end{array}$ & & & \\
\hline & $\begin{array}{l}\text { Pada kawasan telah } \\
\text { tersedia sarana } \\
\text { pengolahan sampah } \\
\text { berupa TPS } 3 R \\
\text { namun tidak } \\
\text { memenuhi } \\
\text { persyaratan. }\end{array}$ & 2 & & \\
\hline & $\begin{array}{l}\text { Pada kawasan tidak } \\
\text { tersedia sarana } \\
\text { pengolahan sampah } \\
\text { berupa TPS } 3 R \text {. }\end{array}$ & 1 & & \\
\hline
\end{tabular}

Pemilahan sampah yang dilakukan di Kampung Batik Laweyan dinilai sangat memenuhi indikator ramah lingkungan karena secara kuantitas Kampung Batik Laweyan telah memenuhi standar ketersediaan pengelolaan sampah pada tahap pengumpulan dan pemindahan, yaitu berupa wadah sampah. Pada tabel skoring tersebut juga didapatkan bahwa teknis kegiatan pengumpulan sampah di Kampung Batik Laweyan dinilai tidak memenuhi indikator ramah lingkungan. Walaupun siklus pengolahan sampah di Kampung Batik Laweyan tidak melalui tahap pengolahan sampah di TPS sejak tahun 2017, hal tersebut tidak mengakibatkan lingkungan menjadi tercemar, melainkan hal ini bertujuan agar tidak terjadinya sampah yang "nginep" di TPS dan tidak ada penumpukan sampah yang menimbulkan pencemaran lingkungan di sekitar TPS. Kota Surakarta mulai menggalakkan TPS berupa mobil sampah yang beroperasi setiap hari dari sumber sampah di permukiman menuju TPA serta secara bertahap menghilangkan TPS yang dinilai kurang efektif dan justru malah menimbulkan pencemaran lingkungan. Selain itu, ditinjau dari teknis kegiatan pengolahan sampah yang dilakukan di Kampung Batik Laweyan dinilai tidak memenuhi indikator ramah lingkungan karena secara eksisting Kampung Batik Laweyan tidak tersedia fasilitas pengolahan sampah berupa TPS 3R serta belum adanya forum penggerak pengolahan sampah daur ulang maupun forum penggerak bank sampah, sehingga sampah yang dihasilkan dari berbagai aktivitas di kampung ini belum dimanfaatkan secara optimal.

3.2.6 Jaringan air bersih yang dapat meningkatkan kualitas air. Air bersih merupakan salah satu kebutuhan dasar yang harus terpenuhi oleh setiap manusia, sehingga keberadaannya dari berbagai sumber akan berpengaruh terhadap kelangsungan hidup. Untuk mencapai kondisi jaringan air bersih yang ramah lingkungan, perlu ditinjau melalui ketersediaannya yang berlaku menurut Permen Perumahan Rakyat RI Nomor 30 Tahun 2011 dan PP Nomor 82 Tahun 2001, yaitu jaringan air bersih yang disalurkan melalui sistem perpipaan distribusi dari PDAM yang terkoneksi dengan lainnya membentuk saluran tertutup serta diindikasikan salah 
satunya melalui kualitas air yang dihasilkan, yaitu kejernihannya, warna, bau, dan rasa. Skoring mengenai variabel jaringan air bersih yang dapat meningkatkan kualitas air di Kampung Batik Laweyan dapat dilihat pada Tabel 8.

Tabel 8. Skoring jaringan air bersih yang dapat meningkatkan kualitas air.

\begin{tabular}{|c|c|c|c|c|}
\hline Sub Variabel & Indikator & Skor & Kondisi Eksisting & $\begin{array}{c}\text { Skor yang } \\
\text { didapatkan }\end{array}$ \\
\hline $\begin{array}{l}\text { Ketersediaan } \\
\text { jaringan air } \\
\text { bersih yang } \\
\text { dapat } \\
\text { meningkatkan } \\
\text { kualitas air }\end{array}$ & $\begin{array}{l}\text { Jaringan air bersih pada } \\
\text { kawasan secara teknis telah } \\
\text { memenuhi standar, yaitu } \\
\text { disalurkan melalui saluran } \\
\text { perpipaan tertutup dan } \\
\text { menghasilkan kualitas air } \\
\text { yang baik (tidak berwarna, } \\
\text { tidak berbau, dan tidak } \\
\text { berasa). } \\
\text { Jaringan air bersih pada } \\
\text { kawasan secara teknis } \\
\text { hanya memenuhi salah } \\
\text { satu dari standar. } \\
\text { Jaringan air bersih pada } \\
\text { kawasan secara teknis tidak } \\
\text { memenuhi standar. }\end{array}$ & 1 & $\begin{array}{l}\text { Penduduk Kampung Batik Laweyan } \\
\text { yang menggunakan air bersih } \\
\text { bersumber dari PDAM Kota } \\
\text { Surakarta hanya berkisar } 48 \% \text { dari } \\
\text { dua jenis sumber air bersih yang } \\
\text { tersedia di kawasan ini, yaitu } \\
\text { sumur (air tanah) dan PDAM. } \\
\text { Adapun jaringan air bersih yang } \\
\text { tersambung ke masing-masing } \\
\text { rumah penduduk menggunakan } \\
\text { sistem perpipaan tertutup dan } \\
\text { kedap air sehingga aman dari } \\
\text { terjadinya pencemaran air. } \\
\text { Sedangkan kualitas air yang } \\
\text { dihasilkan dari jaringan perpipaan } \\
\text { PDAM tersebut sebagian besar } \\
\text { memiliki kualitas yang baik yaitu } \\
\text { tidak berwarna (jernih), tidak } \\
\text { berbau, dan tidak berasa. }\end{array}$ & 3 \\
\hline
\end{tabular}

3.2.7 Ruang terbuka hijau (RTH) yang ramah lingkungan. Ruang terbuka hijau (RTH) adalah ruang terbuka di suatu kawasan yang di dalamnya terdapat vegetasi serta memiliki beberapa fungsi, seperti rekreasi, resapan air, olahraga, dan mengendalikan pencemaran udara. Selain itu, RTH juga memiliki fungsi dapat mengurangi risiko banjir sebagai lahan resapan air hujan. Ketersediaan RTH yang ramah lingkungan ditinjau dari luasannya yaitu minimal $30 \%$ dari luas wilayah/kawasan (Undang Undang Nomor 26 Tahun 2007). Skoring mengenai variabel ruang terbuka hijau yang ramah lingkungan di Kampung Batik Laweyan dapat dilihat pada Tabel 9.

Tabel 9. Skoring RTH yang dapat mengendalikan risiko banjir dan pencemaran udara.

\begin{tabular}{|c|c|c|c|c|}
\hline Sub Variabel & Indikator & Skor & Kondisi Eksisting & $\begin{array}{l}\text { Skor yang } \\
\text { didapatkan }\end{array}$ \\
\hline \multirow{6}{*}{$\begin{array}{l}\text { Luasan RTH yang } \\
\text { dapat } \\
\text { mengendalikan } \\
\text { risiko banjir dan } \\
\text { pencemaran } \\
\text { udara }\end{array}$} & Pada kawasan telah tersedia RTH & & \multirow{6}{*}{$\begin{array}{l}\text { Kampung Batik } \\
\text { Laweyan tersedia RTH } \\
\text { berupa pemakaman } \\
\text { yang berjumlah } 3 \mathrm{di} \\
\text { lokasi yang berbeda } \\
\text { dengan total luasan } \\
\text { sebesar } 4.839 \mathrm{~m}^{2} \text { atau } \\
\text { 1,95\% dari luas seluruh } \\
\text { kawasan. }\end{array}$} & \multirow{6}{*}{ 年 } \\
\hline & $\begin{array}{l}\text { dengan luasan }>\mathbf{3 0} \% \text { dari luas } \\
\text { kawasan seluruhnya }\end{array}$ & 3 & & \\
\hline & Pada kawasan telah tersedia RTH & & & \\
\hline & dengan luasan $<30 \%$ dari luas & 2 & & \\
\hline & kawasan seluruhnya & & & \\
\hline & Pada kawasan tidak tersedia RTH & 1 & & \\
\hline
\end{tabular}


Ruang terbuka hijau (RTH) di Kampung Batik Laweyan dinilai memenuhi indikator ramah lingkungan karena telah tersedia RTH sebagai lahan resapan air guna mengurangi risiko banjir. Namun, secara eksisting luasan RTH di Kampung Batik Laweyan belum memenuhi standar yang berlaku, yaitu hanya mencapai $1,95 \%$ dari luas Kampung Batik Laweyan secara keseluruhan, mengingat pula bahwa Kampung Batik Laweyan termasuk permukiman dengan kepadatan tinggi yang artinya lahan yang penggunaannya sebagai RTH masih tergolong minim.

3.2.8 Analisis kesesuaian infrastruktur Kampung Batik Laweyan berdasarkan konsep ramah lingkungan. Analisis skoring kesesuaian infrastruktur Kampung Batik Laweyan (Tabel 10) bertujuan untuk mengetahui kesesuaian infrastruktur tersebut terhadap indikator ramah lingkungan yang telah dirumuskan. Analisis ini dilakukan dengan menjumlahkan seluruh skor pada sub variabel setiap variabel, kemudian mengkategorikan ke dalam 3 kategori, yaitu kategori kurang sesuai, kategori sesuai, dan kategori sangat sesuai. Setelah didapatkan skor atau nilai dari masing-masing sub variabel, dilakukan perhitungan jumlah skor dari masingmasing variabel untuk mengetahui kesesuaian per variabel terhadap indikator ramah lingkungan. Kemudian, dari hasil perhitungan skor seluruh variabel ditentukan interval pengukuran untuk mengetahui tingkat kesesuaian infrastruktur Kampung Batik Laweyan berdasarkan konsep ramah lingkungan. Interval didapatkan dari jumlah nilai maksimal semua variabel dikurangi jumlah nilai minimal semua variabel dibagi dengan kelas atau pengkategorian yang ditentukan, yakni 3 kategori. Sehingga didapatkan interval sebagai berikut:
12,0-20,0 : kesesuaian rendah
20,1-28,1 : kesesuaian sedang
28,2-36,0 : kesesuaian tinggi

Tabel 10. Skoring kesesuaian tiap variabel.

\begin{tabular}{|c|c|c|c|c|}
\hline \multirow[b]{2}{*}{ Variabel } & \multirow[b]{2}{*}{ Sub Variabel } & \multicolumn{2}{|c|}{ Skor } & \multirow[b]{2}{*}{ Keterangan } \\
\hline & & $\begin{array}{l}\text { Tiap Sub } \\
\text { Variabel }\end{array}$ & $\begin{array}{c}\text { Tiap } \\
\text { Variabel }\end{array}$ & \\
\hline $\begin{array}{l}\text { Jaringan jalan } \\
\text { lingkungan yang } \\
\text { dapat meresap } \\
\text { air hujan }\end{array}$ & $\begin{array}{l}\text { Badan jalan yang dapat meresap } \\
\text { air } \\
\text { Bahu jalan yang dapat meresap } \\
\text { air }\end{array}$ & 3 & 4 & Sesuai \\
\hline $\begin{array}{l}\text { Jaringan listrik } \\
\text { yang } \\
\text { memanfaatkan } \\
\text { sumber daya } \\
\text { energi alternatif } \\
\end{array}$ & $\begin{array}{l}\text { Ketersediaan jaringan listrik } \\
\text { yang memanfaatkan sumber } \\
\text { daya energi alternatif }\end{array}$ & 1 & 1 & Kurang sesuai \\
\hline $\begin{array}{l}\text { Jaringan drainase } \\
\text { yang dapat } \\
\text { mengendalikan } \\
\text { risiko banjir }\end{array}$ & $\begin{array}{l}\text { Sistem peresapan dalam } \\
\text { mengendalikan risiko banjir } \\
\text { Sistem pengaliran dalam } \\
\text { mengendalikan risiko banjir }\end{array}$ & 3 & 6 & Sangat sesuai \\
\hline $\begin{array}{l}\text { Jaringan air } \\
\text { limbah yang }\end{array}$ & $\begin{array}{l}\text { Septic tank dalam } \\
\text { mengendalikan limbah }\end{array}$ & 3 & 6 & Sangat sesuai \\
\hline
\end{tabular}

Received: June 18, 2019; Accepted: July 07, 2019; Available online: July 15, 2021 377 


\begin{tabular}{|c|c|c|c|c|}
\hline \multirow{3}{*}{$\begin{array}{l}\text { Variabel } \\
\text { dapat } \\
\text { mengendalikan } \\
\text { limbah }\end{array}$} & \multirow[b]{2}{*}{ Sub Variabel } & \multicolumn{2}{|c|}{ Skor } & \multirow{3}{*}{ Keterangan } \\
\hline & & $\begin{array}{l}\text { Tiap Sub } \\
\text { Variabel }\end{array}$ & $\begin{array}{c}\text { Tiap } \\
\text { Variabel }\end{array}$ & \\
\hline & $\begin{array}{l}\text { Sistem perpipaan dalam } \\
\text { mengendalikan limbah }\end{array}$ & 3 & & \\
\hline \multirow{3}{*}{$\begin{array}{l}\text { Pengelolaan } \\
\text { persampahan } \\
\text { dalam upaya } \\
\text { pengendalian } \\
\text { limbah }\end{array}$} & $\begin{array}{l}\text { Pemilahan sampah dalam } \\
\text { mengendalian limbah }\end{array}$ & 3 & & \\
\hline & $\begin{array}{l}\text { Pengumpulan sampah dalam } \\
\text { mengendalikan limbah }\end{array}$ & 1 & 5 & Kurang sesuai \\
\hline & $\begin{array}{l}\text { Pengolahan sampah dalam } \\
\text { mengendalikan limbah }\end{array}$ & 1 & & \\
\hline $\begin{array}{l}\text { Jaringan air } \\
\text { bersih yang } \\
\text { dapat } \\
\text { meningkatkan } \\
\text { kualitas air }\end{array}$ & $\begin{array}{l}\text { Ketersediaan jaringan air bersih } \\
\text { yang dapat meningkatan } \\
\text { kualitas air }\end{array}$ & 3 & 3 & Sangat Sesuai \\
\hline \multirow{2}{*}{$\begin{array}{l}\text { Ruang terbuka } \\
\text { hijau (RTH) yang } \\
\text { dapat } \\
\text { mengendalikan } \\
\text { risiko banjir dan } \\
\text { pencemaran } \\
\text { udara }\end{array}$} & $\begin{array}{l}\text { Luasan RTH yang dapat } \\
\text { mengendalikan risiko banjir dan } \\
\text { pencemaran udara }\end{array}$ & 2 & 2 & Sesuai \\
\hline & Jumlah skor & 27 & 27 & \\
\hline
\end{tabular}

Berdasarkan tabel di atas didapatkan jumlah skor perhitungan kesesuaian tiap variabel terhadap indikator ramah lingkungan adalah 27, yang artinya tergolong pada kategori kesesuaian sedang. Sehingga, dapat disimpulkan bahwa semua jenis infrastruktur pada tiap variabel penelitian di Kampung Batik Laweyan memiliki kondisi secara kualitas maupun kuantitas cukup memenuhi terhadap indikator ramah lingkungan.

Variabel yang sangat sesuai terhadap indikator ramah lingkungan terdiri dari variabel jaringan drainase, jaringan air limbah, dan variabel jaringan air bersih. Hal tersebut didasarkan pada kondisi eksisting masing-masing infrastruktur yang terbilang ramah lingkungan baik dari segi kualitas maupun kuantitasnya. Keberadaan infrastruktur tersebut tidak berdampak buruk bagi lingkungan dan tidak menghambat masyarakat di Kampung Batik Laweyan dalam melakukan aktivitasnya. Sedangkan variabel yang dikategorikan kurang sesuai terhadap indikator ramah lingkungan adalah variabel jaringan listrik dan pengelolaan persampahan. Dalam pendistribusian energi listrik ke masing-masing rumah penduduk, perlu diperhatikan dari mana sumber energi listrik tersebut dan bagaimana kualitas maupun kuantitasnya, agar tercipta keharmonisan dalam penggunaan terutama dampaknya bagi lingkungan. Kondisi 
jaringan listrik yang ramah lingkungan yaitu listrik yang memanfaatkan sumber daya energi alternatif atau sumber energi yang dapat diperbaharui. Namun pada kenyataannya, jaringan listrik di Kampung Batik Laweyan masih minim dalam menggunakan energi alternatif sehingga dikhawatirkan dapat menimbulkan dampak negatif jangka panjang bagi lingkungan di dalam maupun luar kawasan akibat penggunaan listrik dari sumber energi non-terbarukan. Selain itu, pengelolaan persampahan di Kampung Batik Laweyan masih kurang kesesuaiannya terhadap infrastruktur ramah lingkungan karena berdasarkan teknis kegiatan pengumpulan dan pengolahan sampah belum menyediakan TPS dan TPS 3R melainkan sampah langsung diangkut menuju TPA tanpa ada upaya menjadikan sampah yang dapat didaur ulang sebagai sampah yang bermanfaat baik dari segi ekonomi maupun keterampilan.

\section{Kesimpulan}

Berdasarkan hasil analisis dan pembahasan yang telah dilakukan dalam penelitian terkait tingkat kesesuaian infrastruktur Kampung Batik Laweyan Kota Surakarta berdasarkan konsep ramah lingkungan, dapat disimpulkan beberapa hal yakni sebagai berikut.

a. Infrastruktur yang tersedia di Kampung Batik Laweyan merupakan infrastruktur yang mendukung dan melayani seluruh aktivitas di dalamnya, yakni infrastruktur permukiman, infrastruktur kawasan pariwisata, maupun infrastruktur kawasan industri rumah tangga.

b. Jenis infrastruktur di Kampung Batik Laweyan yang teridentifikasi terdiri dari jaringan jalan lingkungan, jaringan listrik, jaringan drainase, jaringan air limbah rumah tangga, jaringan air limbah industri batik rumah tangga, jaringan air bersih, pengelolaan persampahan, dan ruang terbuka hijau (RTH). Jenis infrastruktur tersebut dinilai kurang sesuai dari teori yang telah didapatkan terkait jenis infrastruktur minimal yang harus dipenuhi pada kawasan kampung wisata batik, yaitu tidak tersedianya jaringan gas dan jaringan telekomunikasi berupa BTS.

c. Infrastruktur yang ramah lingkungan didapatkan dari hasil perumusan terhadap teori ramah lingkungan, sehingga ketersediaan infrastruktur yang ramah lingkungan di Kampung Batik Laweyan akan berpengaruh terhadap keberlanjutan kawasan. Adapun penyediaan infrastruktur di Kampung Batik Laweyan yang ramah lingkungan meliputi jalan lingkungan yang dapat meresap air untuk mengelola air hujan, jaringan listrik yang memanfaatkan sumber daya energi alternatif, jaringan pembuangan air yang dapat mengurangi risiko banjir dan dapat mengurangi limbah, pengelolaan persampahan dalam upaya pengurangan limbah, pemanfaatan sumber daya air bersih dengan memperhatikan kualitasnya, RTH yang dapat mengurangi risiko banjir serta dapat mengendalikan pencemaran udara dan peningkatan kesehatan lingkungan.

d. Penentuan tingkat kesesuaian infrastruktur terhadap konsep ramah lingkungan pada penelitian ini dibagi menjadi 3 (tiga) kategori, yakni kurang sesuai, sesuai, dan sangat sesuai. Jenis infrastruktur yang tergolong kurang sesuai terhadap konsep ramah lingkungan, yaitu jaringan listrik dan pengelolaan persampahan. Selain itu, jenis infrastruktur di Kampung Batik Laweyan yang tergolong sesuai terhadap konsep ramah lingkungan, yaitu jaringan jalan lingkungan dan ruang terbuka hijau (RTH). Sedangkan jenis infrastruktur yang tergolong sangat sesuai terhadap konsep ramah lingkungan adalah jaringan drainase, jaringan air limbah, dan jaringan air bersih. 


\section{Referensi}

[1] Sumintarsih, Adrianto A. Dinamika Kampung Kota: Prawirotaman dalam Perspektif Sejarah dan Budaya. Yogyakarta: Balai Pelestarian Nilai Budaya (BPNB) Yogyakarta; 2014.

[2] Basri H, Ispurwono, Soemardiono B. Model Penanganan Permukiman Kumuh. Semin. Nas. Permukim. dalam Pembang. Kota, Surabaya: ITS; 2010.

[3] Djoemena N, Surianata N. Ungkapan Sehelai Batik: Its Mystery and Meaning. Jakarta: Djambatan; 1986.

[4] Pemerintah Kota Surakarta. Surat Keputusan (SK) Walikota Surakarta No. 534.05/136B/1/2004 tentang Panitia Pelaksanaan Pembentukan Kawasan Batik Laweyan. 2004.

[5] Pemerintah Kota Surakarta. Peraturan Daerah Kota Surakarta Nomor 1 Tahun 2012 tentang Rencana tata Ruang Wilayah Kota Surakarta Tahun 2011-2031 2012.

[6] Kodoatie RJ. Pengantar Manajemen Infrastruktur. Yogyakarta: Pustaka Pelajar; 2005.

[7] Warsilan, Noor A. Peranan Infrastruktur terhadap Pertumbuhan Ekonomi dan Implikasi pada Kebijakan Pembangunan di Kota Samarinda. MIMBAR 2015;31:359-66. https://doi.org/10.29313/mimbar.v31i2.1444.

[8] Pemerintah Kota Surakarta. Rencana Pembangunan Kawasan Permukiman Prioritas Kota Surakarta 2014.

[9] Tim Pengelola Website Kemenperin. Siaran Pers: Pewarna Alam Batik Kurangi Impor Sintetik 2017.

[10] Republik Indonesia. Undang Undang Republik Indonesia Nomor 26 Tahun 2007 Tentang Penataan Ruang. 2007.

[11] Suryana. Metodologi Penelitian: Model Prakatis Penelitian Kuantitatif dan Kualitatif. Bandung: Universitas Pendidikan Indonesia; 2010.

[12] Peraturan Menteri Negara Perumahan Rakyat RI Nomor 32 Tahun 2006 tentang Petunjuk Teknis Kawasan Siap Bangun dan Lingkungan Siap Bangun yang Berdiri Sendiri n.d.

[13] Puro S, Atmiwyastuti N, Restina N. Kritik Dan Pemecahan Penggunaan Konstruksi Beton Cor Pada Rekayasa Jalan Dalam Upaya Membangun Konstruksi Jalan Yang Berkelanjutan. J Media Tek Sipil 2015;12:160-5. https://doi.org/10.22219/jmts.v12i2.2289.

[14] Liun E. Potensi Energi Alternatif dalam Sistem Kelistrikan Indonesia. Semin. Nas. Pengemb. Energi NukI. IV, Jakarta: BATAN; 2011, p. 311-22.

[15] SNI 03-1733-2004. Tata Cara Perencanaan Lingkungan Perumahan di Perkotaan. Jakarta: Badan Standarisasi Nasional; 2004.

[16] Badan Standarisasi Nasional. SNI 03-2398-2002 Tata Cara Perencanaan Tangki Septik dengan Distem Resapan. 2002.

[17] Kementerian Pekerjaan Umum. Permen PUPR No. 12/PRT/M/2014 Tahun 2014 tentang Penyelenggaraan Sistem Drainase Perkotaan. 2014.

[18] Republik Indonesia. Undang Undang Republik Indonesia Nomor 7 Tahun 2004 tentang Pengelolaan Sumber Daya Air. 2004.

[19] Kementerian Negara Perumahan Rakyat. Peraturan Menteri Negara Perumahan Rakyat RI Nomor 30 Tahun 2011 tentang Petunjuk Teknis Penggunaan Dana Alokasi Khusus 
Bidang Perumahan dan Kawasan Permukiman Tahun Anggaran 2012. 2011.

[20] Kementrian Pekerjaan Umum dan Perumahan Rakyat. Panduan Penyusunan Rancangan Peraturan Daerah Tentang Pengelolaan Air Limbah Domestik. Jakarta: Kementrian PUPR; 2015.

[21] Badan Standarisasi Nasional. SNI 03-7065-2005 Tata Cara Perencanaan Sistem Plambing. 2005.

[22] Republik Indonesia. Peraturan Pemerintah Nomor 81 Tahun 2012 tentang Pengelolaan Sampah Rumah Tangga dan Sampah Sejenis Sampah Rumah Tangga. 2012.

[23] Kementerian Pekerjaan Umum. Peraturan Menteri Pekerjaan Umum Nomor 3 Tahun 2013 tentang Penyelenggaraan Prasarana dan Sarana Persampahan dalam Penanganan Sampah Rumah Tangga dan Sampah Sejenis Sampah Rumah Tangga. 2013.

[24] Republik Indonesia. Peraturan Pemerintah RI Nomor 82 Tahun 2001 tentang Pengelolaan Kualitas Air dan Pengendalian Pencemaran Air. 2001.

[25] Republik Indonesia. Undang-Undang Nomor 26 Tahun 2007 Tentang Penataan Ruang 2007.

[26] Badan Standarisasi Nasional. SNI 03-2453-2002 Tata Cara Perencanaan Sumur Resapan Air Hujan Untuk Lahan Pekarangan. 2002.

[27] Kementerian Pekerjaan Umum. Peraturan Menteri Pekerjaan Umum RI Nomor 12 Tahun 2014 tentang Drainase Perkotaan. 2014. 